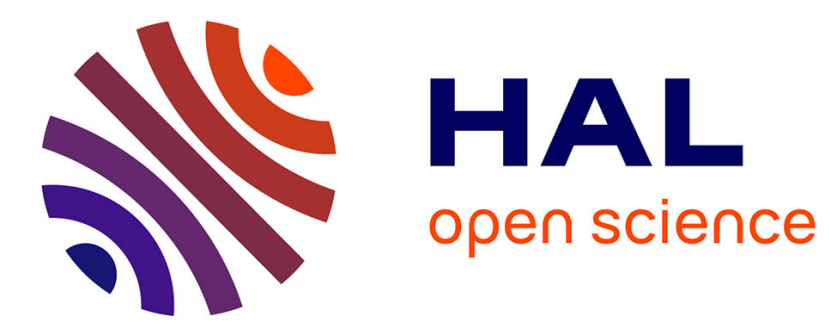

\title{
Layered structure of a supramolecular hybrid sulfate salts: thermal stability and magnetic behavior
}

Omar Kammoun, Houcine Naïli, Walid Rekik, Thierry Bataille

\section{To cite this version:}

Omar Kammoun, Houcine Naïli, Walid Rekik, Thierry Bataille. Layered structure of a supramolecular hybrid sulfate salts: thermal stability and magnetic behavior. Inorganica Chimica Acta, 2015, 434, pp.209-214. 10.1016/j.ica.2015.05.031 . hal-01162337

\section{HAL Id: hal-01162337 \\ https://hal-univ-rennes1.archives-ouvertes.fr/hal-01162337}

Submitted on 18 Nov 2015

HAL is a multi-disciplinary open access archive for the deposit and dissemination of scientific research documents, whether they are published or not. The documents may come from teaching and research institutions in France or abroad, or from public or private research centers.
L'archive ouverte pluridisciplinaire HAL, est destinée au dépôt et à la diffusion de documents scientifiques de niveau recherche, publiés ou non, émanant des établissements d'enseignement et de recherche français ou étrangers, des laboratoires publics ou privés. 


\title{
Layered structure of a supramolecular hybrid sulfate salts: thermal stability and magnetic behavior
}

\author{
Omar KAMMOUN ${ }^{\mathrm{a}, \mathrm{b}}$, Houcine NAÏLI ${ }^{\mathrm{a}^{*}}$, Walid REKIK ${ }^{\mathrm{a}}$ and Thierry BATAILLE ${ }^{\mathrm{b}}$ \\ ${ }^{a}$ Laboratoire Physicochimie de l'Etat Solide, Département de Chimie, Faculté des Sciences de Sfax, Université de Sfax, \\ BP 1171, 3000 Sfax, Tunisie. \\ ${ }^{b}$ Institut des Sciences Chimiques de Rennes (CNRS, UMR 6226), UEB, Université de Rennes 1, 263 avenue du Général \\ Leclerc, F-35042 Rennes Cedex, France. \\ * Corresponding author E-mail: houcine_naili@yahoo.com
}

\begin{abstract}
The incorporation of the aromatic diamine 2-methylimidazole as template in the synthesis of hybrid sulfate salts with transition metal was effected by the slow eyaporation method. The resulting structure presents a lamellar character with a supramolecular network, which is uncommon in the family of sulfates and their derivates. The three synthesized compound with the general formula $\left(\mathrm{C}_{4} \mathrm{H}_{7} \mathrm{~N}_{2}\right)_{2}\left[\mathrm{M}^{\mathrm{II}}\left(\mathrm{H}_{2} \mathrm{O}\right)_{6}\right]\left(\mathrm{SO}_{4}\right)_{2} \cdot 2 \mathrm{H}_{2} \mathrm{O}\left(\mathrm{M}^{\mathrm{II}}=\mathrm{Zn}, \mathrm{Co}\right.$ and $\left.\mathrm{Mn}\right)$ crystallize in the monoclinic symmetry, space group $P 2_{1} / c$. According to the design shape of the protonated amine and its bonding relations between the supramolecular inorganic layers, building from hydrogen bond only, the interlamellar distance reached 11.6 $\AA$. The $\pi$-stacking between aromatic moieties of amines have a relevant role in stabilizing the lamellar structure. The thermal study with in situ powder X-ray diffraction and thermogravimetry of the synthesized compounds showed that the dehydration stage of precursors lead to the formation of an anhydrous crystalline phase with a good thermal stability. Beyond this and under the decomposition stage, Co and $\mathrm{Zn}$ compound become amorphous whereas the Mn-based compound showed successive crystalline phases. The magnetic measurements performed for the cobalt based compound indicate a low interaction exchange within the material in agreement with a typical paramagnetic behavior.
\end{abstract}

Keywords: hybrid material, lamellar structure, supramolecular, sulfate salt. 


\section{Introduction}

Hybrid organic-inorganic materials have been the challenge for the development of industry and the desire to cover new features in multiple domains offering the possibility of combining the dissimilar properties of organic and inorganic components [1-6]. Hybrid layered materials, whose crystal structure might consist in stacked inorganic sheets with intercalated inorganic and/or organic guests, represent an interesting opportunity for developing new materials in different fields of applications, such as nonlinear optical materials, conductors, photoactive materials, nanomagnets, polymer additives, ion-exchangers, electrodes and catalysis [1,3]. Various types of hybrid PCPs (Porous Coordination Polymers) [7], 2D MOFs (Metal Organic Frameworks) [8] or layered/clays inorganic compounds [9], exhibit selective catalytic activities towards many small organic molecules. In particular, layered structures governed by weak bonding energy in one or two lattice directions are one of the most studied and used [9].

Amongst them, hybrid supramolecular compounds represent an interesting opportunity for the development of new materials in various fields of applications, as dielectrics, semiconductors and materials for ONL [10,11]. Many transition metal [12], lanthanide [13], and actinides [14] sulfates combining the organic molecules as template have been developed. The particularity of the templating role of amine and their importance was shown in several applications, such as optics and catalysis [1520]. Organic-inorganic sulfates salts built from transition metals and amines have been mainly described in the literature as supramolecular crystal structures belonging to well-known families as alums and Tutton's salts [21-23]. In this context, we are interested in mixed transition metal sulfates and protonated amines with good thermal stability and which can present reversible phase transitions, for potential applications as dielectric or catalysts [24]. Our recent research activity was introducing aromaticity and/or delocalization of electrons through using aromatic amine as structuring agent in the synthesis of new hybrid sulfates. As a result, an uncommon structure type that gathers between 
supramolecular and lamellar Aspect was highlighted $[\mathbf{2 5 , 2 6}$. It seems that the use of various types of amine molecules onto the synthetic reactions of new hybrid double sulates of transition metals can generate a wider variety of structure topologies. The intention is the incorporation of 2methylimidazole diamine $\left(\mathrm{C}_{4} \mathrm{H}_{5} \mathrm{~N}_{2}\right)$ and the investigation of its influence in this calss of materials. 2methylimidazole is a heterocyclic amine soluble in water characterized by the presence of a hydrophobic methyl group linked to an aromatic five-heterocycle which contain two nitrogen atoms as a hydrophilic diamine part that can accepts hydrogen bonding. We demonstrated in a previous work that zinc-based sulfates including 2-methylimidazole for which a short structure description was given, possess a catalytic activity towards a diastereoselective separation through the nitroaldol reaction [27]. In the present study, the crystal structure of members of $\left(\mathrm{C}_{4} \mathrm{H}_{7} \mathrm{~N}_{2}\right)_{2}\left[\mathrm{M}^{\mathrm{II}}\left(\mathrm{H}_{2} \mathrm{O}\right)_{6}\right]\left(\mathrm{SO}_{4}\right)_{2} \cdot 2 \mathrm{H}_{2} \mathrm{O}$ is described in detail. An interest for the significant effect of the aromatic diamine template is given. A thermal study showing the structural evolution of materials in different stages was performed. Also, the magnetic behavior was presented.

\section{Experimental Section}

\section{1. Materials}

$\mathrm{CoSO}_{4} \cdot 6 \mathrm{H}_{2} \mathrm{O}\left(98 \%\right.$, PROLABO), $\mathrm{ZnSO}_{4} \cdot 7 \mathrm{H}_{2} \mathrm{O}\left(99 \%\right.$, CARLO ERBA), $\mathrm{MnSO}_{4} \cdot \mathrm{H}_{2} \mathrm{O}(98 \%$, Prolabo), 2-Methylimidazol $\mathrm{C}_{4} \mathrm{H}_{6} \mathrm{~N}_{2}$ (99\%, Aldrich), $\mathrm{H}_{2} \mathrm{SO}_{4}$ (97\%, Aldrich) were acquired from commercial sources and used as received.

\section{2. Synthesis}

Crystals of materials with the general formula $\left(\mathrm{C}_{4} \mathrm{H}_{7} \mathrm{~N}_{2}\right)_{2}\left[\mathrm{M}^{\mathrm{II}}\left(\mathrm{H}_{2} \mathrm{O}\right)_{6}\right]\left(\mathrm{SO}_{4}\right)_{2} \cdot 2 \mathrm{H}_{2} \mathrm{O}$ were obtained by crystallisation in solution at room temperature (slow evaporation method). The metal sulfate hydrate $\left(0.287 \mathrm{~g}\right.$ of $\mathrm{ZnSO}_{4} \cdot 7 \mathrm{H}_{2} \mathrm{O}$ or $0.280 \mathrm{~g}$ of $\mathrm{CoSO}_{4} \cdot 7 \mathrm{H}_{2} \mathrm{O}$ or $0.169 \mathrm{~g}$ of $\left.\mathrm{MnSO}_{4} \cdot \mathrm{H}_{2} \mathrm{O}\right)$ and $0.246 \mathrm{~g}$ of 2-methylimidazole amine (MZL) were dissolved, in the proportions of 1 metal / 3 amine, in 
$10 \mathrm{ml}$ of distilled water by magnetic stirring. The $\mathrm{pH}$ of each solution (ZnMZL, CoMZL and MnMZL) was adjusted between 2 and 3 by dropwise addition of concentrated sulfuric acid $\mathrm{H}_{2} \mathrm{SO}_{4}$ until the solution becomes clear. The formed crystals were collected by filtration and washed with a small amount of distilled water before being dried in ambient air.

\section{3. Single-Crystal Data Collection and Structure Determination}

A suitable crystal of CoMZL compound was glued to a glass fiber mounted on APEX II area detector 4-circles diffractometer. Intensity data sets were collected using Mo Ka radiation (0.71073 A) through the Bruker AXS APEX2 Sofware Suite. The crystal structure of compounds possessing the general formula $\left(\mathrm{C}_{4} \mathrm{H}_{7} \mathrm{~N}_{2}\right)_{2}\left[\mathrm{M}^{\mathrm{II}}\left(\mathrm{H}_{2} \mathrm{O}\right)_{6}\right]\left(\mathrm{SO}_{4}\right)_{2} \cdot 2 \mathrm{H}_{2} \mathrm{O}$ with $\mathrm{M}^{\mathrm{II}}=\mathrm{Zn}$, Co was determined in the monoclinic symmetry, space group $P 2_{1} / c$. The atoms of the metal, sulfur, oxygen and the nitrogen of the aromatic amine were located using the direct methods with the program SIR97 [28]. The positions of the carbon atoms of amine molecule were found from successive difference Fourier calculations using SHELXL97 [29]. The hydrogen atoms linked to the carbons were fixed geometrically and restrained via HFIX command of SHELXL97 program, while the other hydrogen atoms were found and refined by several cycles of refinements. Within a water molecule, the $\mathrm{O}-\mathrm{H}$ and $\mathrm{H}-\mathrm{H}$ distances have been restrained to give the ideal value for $\mathrm{H}-\mathrm{O}-\mathrm{H}$ angle. The atomic displacement parameters of the $\mathrm{H}$ atoms were fixed at $1.5 U_{\text {eq }}$ of their parent atom. Crystallographic data are given in Table 1.

\section{4. X-Ray powder diffraction}

X-Ray powder diffraction data of ground crystals of MnMZL compound were collected at room temperature with a Bruker D8 diffractometer, with the parafocusing Bragg-Brentano geometry, using monochromatic $\mathrm{Cu} \mathrm{K \alpha 1}$ radiation $(\lambda=1.5406 \AA)$ selected with an incident beam curved-crystal germanium monochromator. The diffraction pattern was collected over the angular range $5-110^{\circ}(2 \theta)$ with a counting time of $4 \mathrm{~s}$ per step and a step length of $0.02(2 \theta)$. X-ray powder diffraction patterns of CoMZL and ZnMZL compounds are simulated from single crystal structures (Fig. 1). 


\section{5. Thermal analyses}

Temperature-dependent X-ray powder diffraction (TDXD) were carried out with a $\theta-\theta$ Bruker AXS D8 Advance powder diffractometer, equipped with a high-temperature Anton Paar HTK1200 oven camera and a LynxEye detector. Powder patterns were collected sequentially upon heating at $21.6{ }^{\circ} \mathrm{C} \mathrm{h}^{-1}$ up to $400{ }^{\circ} \mathrm{C}$, with the monochromatized $\mathrm{CuK \alpha}$ 1 radiation $(\lambda=1.5406 \AA)$. To ensure satisfactory counting statistics, counting times of $20 \mathrm{~min} /$ pattern were selected for the thermal decomposition of the precursors, so that any pattern could be collected within a temperature range of $7.2^{\circ} \mathrm{C}$.

TGA/DSC measurement was performed with a TA SDT Q600 instrument in flowing air, for any compound, with a heating rate of $0.5^{\circ} \mathrm{C} \min ^{-1}$ up to $600{ }^{\circ} \mathrm{C}$.

\section{6. Magnetic measurements}

Magnetic susceptibility measurement in the range of 2-300 K was carried out on a powdered sample of the cobalt based compound, at the magnetic field of $1000 \mathrm{Oe}$, using a Quantum Design SQUID Magnetometer (type MPMS-XL5).

\section{Results and Discussion}

\section{1. Crystal structures}

The synthesized hybrid materials with the general formula $\left(\mathrm{C}_{4} \mathrm{H}_{7} \mathrm{~N}_{2}\right)_{2}\left[\mathrm{M}^{\mathrm{II}}\left(\mathrm{H}_{2} \mathrm{O}\right)_{6}\right]\left(\mathrm{SO}_{4}\right)_{2} \cdot 2 \mathrm{H}_{2} \mathrm{O}$ $\left(\mathrm{M}^{\mathrm{II}}=\mathrm{Zn}, \mathrm{Co}\right.$ and $\left.\mathrm{Mn}\right)$ are isostructural and crystallize in the monoclinic symmetry, space group $P 2_{1} / c$ (Fig. 1). The crystal structure of each compound shows a lamellar feature with a fully supramolecular network. It is built from the stacking of anionic inorganic layers of $\left(\left[\mathrm{M}^{\mathrm{II}}\left(\mathrm{H}_{2} \mathrm{O}\right)_{6}\right]\left(\mathrm{SO}_{4}\right)_{2} \cdot 2 \mathrm{H}_{2} \mathrm{O}\right)^{2-}$ along the crystallographic $b$ axis, between which are located the 2-methylimidazolium cations $\left(\mathrm{C}_{4} \mathrm{H}_{7} \mathrm{~N}_{2}\right)^{+}$in such a way to compensate the negative charges of the inorganic part (fig. 2a).

The inorganic layer is parallel to the $(\mathrm{a}, \mathrm{c})$ plane and is constructed by the metal octahedra, sulfate tetrahedra and the free water molecules interconnected and stabilized via $\mathrm{O}-\mathrm{H} \cdots \mathrm{O}$ hydrogen 
bond only, giving rise to a pseudo $2 \mathrm{D}$ inorganic layer. The metal octahedra $\left[\mathrm{M}^{\mathrm{II}}\left(\mathrm{H}_{2} \mathrm{O}\right)_{6}\right]^{2+}$ and the free water molecules are located on the mean plane of the layer and form a positively charged sheet, which is limited by two negatively charged sheet of sulfate tetrahedra $\left(\mathrm{SO}_{4}\right)^{2-}$ at the upper and the lower sides (fig. 2b).

The free water molecules play an important role to provide the supramolecular aspect of the inorganic layer forming a connecting bridge between inorganic anions and cations. Indeed, the oxygen of $\mathrm{H}_{2} \mathrm{O}$ molecule may be, at the same time, an hydrogen bond acceptor given from oxygen atom of water molecule coordinated to the metallic octahedron and an hydrogen bond donor toward oxygen of anionic sulfate.

The protonated amines are arranged in [001] single direction between the mineral layers (fig. 2c). They are linked to the mineral part through connecting the sulfate groups by $\mathrm{N}-\mathrm{H} \cdots \mathrm{O}$ hydrogen bond and they interact with each other by weak $\pi-\pi$ interactions. These interactions are made following a parallel-displaced configuration of amine aromatic rings $[\mathbf{3 0 , 3 1}]$. Hence, the distance between two parallel planes of two aromatic rings of adjacent amine is of the order of $3.3 \AA$. Within the amine molecule, the C-N and C-C distances are close to the usual values observed in others homologous derivates.

Adjacent layers are organized through coulomb attraction between the positive imidazolium group of 2-metylimidazolium molecule and the sulfate group supported by charge-assisted $\mathrm{N}-\mathrm{H} \cdots \mathrm{O}^{(-)}$ hydrogen bond. Again, these charge assisted interactions are clearly seen as the driving force of the inorganic layer formation through developing $\mathrm{O}-\mathrm{H}^{\cdots} \mathrm{O}^{(-)}$bonding between water molecules and sulfate group. Stability of the crystal structure is probably due to this type of strong hydrogen bonding especially between the organic part and the inorganic framework [32 - 39].

The interlayer distance that corresponds to the distance between the mean planes of two adjacent inorganic layers is equal to $11.67 \AA$, i.e, the equivalent to the half of the $b$ parameter of the 
crystallographic unit cell (table 1). This interlayer distance can be modified depending upon on the amine template incorporated into the structure. Such structural arrangement, which can readily be related to layered materials with supramolecular appearance, is observed in the organic-inorganic sulfate salts incorporating $\alpha$-methylbenzylamine $\left(\mathrm{C}_{8} \mathrm{H}_{12} \mathrm{~N}\right)_{2}\left[\mathrm{M}^{\mathrm{II}}\left(\mathrm{H}_{2} \mathrm{O}\right)_{4}\left(\mathrm{SO}_{4}\right)_{2}\right] \cdot 2 \mathrm{H}_{2} \mathrm{O}(\mathrm{M}=\mathrm{Fe}$ to $\mathrm{Zn})$ where the layers are built from mineral entities exhibiting more important interlamellar distance i.e. 16 $\AA$ [25]. The templating role of benzimidazole amine in $\left(\mathrm{C}_{7} \mathrm{H}_{7} \mathrm{~N}_{2}\right)_{2}\left[\mathrm{M}^{\mathrm{II}}\left(\mathrm{H}_{2} \mathrm{O}\right)_{6}\right]\left(\mathrm{SO}_{4}\right)_{2} \cdot 4 \mathrm{H}_{2} \mathrm{O}\left(\mathrm{M}^{\mathrm{II}}=\mathrm{Zn}\right.$, $\mathrm{Cu}, \mathrm{Ni}, \mathrm{Co})$ and $\left(\mathrm{C}_{7} \mathrm{H}_{7} \mathrm{~N}_{2}\right)_{2}\left[\mathrm{Fe}\left(\mathrm{H}_{2} \mathrm{O}\right)_{6}\right]\left(\mathrm{SO}_{4}\right)_{2} \cdot 3 \mathrm{H}_{2} \mathrm{O}$ materials can modify the interlayer space from 12.3 to $13.2 \AA$ depending upon on the nature of the metal [26]. Another lanthanum sulfate salt $\mathrm{La}_{2}\left(\mathrm{H}_{2} \mathrm{O}\right)_{2}\left(\mathrm{C}_{4} \mathrm{H}_{12} \mathrm{~N}_{2}\right)\left(\mathrm{SO}_{4}\right)_{4}$ possessing anionic sheets has an interlayer distance of $13.4 \AA$ [40]. We can observe distances beyond mainly in $2 D$ lamellar structures, such as in clay materials $[\mathbf{4 1 , 4 2 ]}$. Others exemples of hybrid metal complexes and phosphate salts having a supramolecular structures with a lamellar feature show a crystal packing arrangement organized by separation between hydrophilic interior and hydrophobic exterior parts alternating along the longest crystallographic direction axis i.e. in the stacking direction [43 - 45].

The building units of the structure includes one protonated amine, one sulfate tetrahedron, a metallic octahedron coordinated by $6 \mathrm{H}_{2} \mathrm{O}$ lying in a special position and one free water molecule. The metal atom occupies a special position on the centre of symmetry of the space group. Its coordination sphere is composed of 6 oxygen atoms from six water molecules including three crystallographically independent. Four of them are in equatorial positions and two in apical positions. The coordination polyhedron thus formed is a quasi-regular octahedron (fig. 2d).

Within the inorganic layer, the intermetallic shortest distances separating two metal octahedra are c.a. $6.66 \AA$. These distances are closer to those observed in 2-methylpiperazine related sulfate compounds exhibiting the same supramolecular network between the same $\left[\mathrm{M}^{\mathrm{II}}\left(\mathrm{H}_{2} \mathrm{O}\right)_{6}\right]^{2+}$ entities, such as, $\mathrm{Co} \cdots \mathrm{Co}=6.60 \AA$ in $\left(\mathrm{C}_{5} \mathrm{H}_{14} \mathrm{~N}_{2}\right)\left[\mathrm{Co}\left(\mathrm{H}_{2} \mathrm{O}\right)_{6}\right]\left(\mathrm{SO}_{4}\right)_{2}[46]$. 


\section{2. Thermal decomposition}

Thermal stability is an important opportunity for lamellar materials like clay minerals (modified montmorillonite) [47] and some hybrid layered materials as many phosphonates, known for their intercalation and catalytic properties $[\mathbf{4 8 , 4 9 ]}$. In the fact of the supramolecular lamellar feature of the structure design of our precursors, we decide to give a thorough thermal study to investigate their thermal stability.

The thermal decomposition of the compounds $\left(\mathrm{C}_{4} \mathrm{H}_{7} \mathrm{~N}_{2}\right)_{2}\left[\mathrm{M}^{\mathrm{II}}\left(\mathrm{H}_{2} \mathrm{O}\right)_{6}\right]\left(\mathrm{SO}_{4}\right)_{2} \cdot 2 \mathrm{H}_{2} \mathrm{O}\left(\mathrm{M}^{\mathrm{II}}=\mathrm{Zn}\right.$, Co and Mn) was studied by in situ X ray powder diffraction (TDXD) and thermogravimetry (TG). The thermal behavior is almost the same for all precursors and transformations differ only by the temperature intervals. Indeed, we note the same succession of steps. First, a complete dehydration to yield an anhydrous crystalline phase which is stable over a wide range of temperature, then, a decomposition of the anhydrous phase accompanied with a loss of crystallinity. At higher temperatures (300 - $\left.400{ }^{\circ} \mathrm{C}\right)$, a completely amorphous phases are formed for zinc and cobalt compounds. For Mnbased material, we see the formation of crystalline phases from $336^{\circ} \mathrm{C}$.

\section{2. 1. Thermal decomposition of $\left(\mathrm{C}_{4} \mathrm{H}_{7} \mathrm{~N}_{2}\right)_{2}\left[\mathrm{Co}\left(\mathrm{H}_{2} \mathrm{O}\right)_{6}\right]\left(\mathrm{SO}_{4}\right)_{2} \cdot 2 \mathrm{H}_{2} \mathrm{O}$}

Data given from thermogravimetric analyses (fig. 3) show that under dynamic air heating at a rate of $0.5^{\circ} \mathrm{C} \cdot \mathrm{min}^{-1},\left(\mathrm{C}_{4} \mathrm{H}_{7} \mathrm{~N}_{2}\right)_{2}\left[\mathrm{Co}\left(\mathrm{H}_{2} \mathrm{O}\right)_{6}\right]\left(\mathrm{SO}_{4}\right)_{2} \cdot 2 \mathrm{H}_{2} \mathrm{O}$ undergoes a first mass loss of $24.13 \%$ between room temperature and $70^{\circ} \mathrm{C}$, accompanied by an endothermic DSC signal. This mass loss corresponds to the departure of 8 water molecules (theoretical loss, $25.66 \%$ ), from which the complete dehydration of the precursor and the formation of the anhydrous $\left(\mathrm{C}_{4} \mathrm{H}_{7} \mathrm{~N}_{2}\right)_{2} \mathrm{Co}\left(\mathrm{SO}_{4}\right)_{2}$. The latter remains stable up to $200{ }^{\circ} \mathrm{C}$. Beyond this temperature, the decomposition initiate in two stages leading to the final residue of $21.68 \%$ corresponding to $1 / 2\left(\mathrm{CoO}+\mathrm{CoSO}_{4}\right)$ at $600{ }^{\circ} \mathrm{C}$ (theoretical value, $\left.20.49 \%\right)$. The first stage of decomposition between 200 and $300^{\circ} \mathrm{C}$ is a mass loss of about $8.96 \%$ coupled with an 
endothermic heat flow. The second decomposition step is more important (mass loss of about 41.13\%), it occurs between 300 and $500^{\circ} \mathrm{C}$ and is accompanied with an exothermic peak on the DSC curve.

An X-ray powder diffraction study according to the temperature (fig. 4) shows that the anhydrous phase $\left(\mathrm{C}_{4} \mathrm{H}_{7} \mathrm{~N}_{2}\right)_{2} \mathrm{Co}\left(\mathrm{SO}_{4}\right)_{2}$ is crystallized and it is stable between $62{ }^{\circ} \mathrm{C}$ and $235{ }^{\circ} \mathrm{C}$. It undergoes a small transition manifested by a small change in the shape of the diffraction patterns at $113{ }^{\circ} \mathrm{C}$. From $235^{\circ} \mathrm{C}, \mathrm{XRD}$ data show that the crystallinity of the phases decreases strongly to result in an amorphous product at $300^{\circ} \mathrm{C}$ (decomposition phase).

The weight losses associated with the steps of diffraction patterns changes can allowed proposing chemical formula for the anhydrous phase. After a complete dehydration, these materials will undergo structural changes. Indeed, the water molecules connected to the metal cation will be released, and a rearrangement of the metal polyhedron is still possible. It is assumed that the metal in the anhydrous phase will be surrounded by the sulfate groups instead of water molecules. So that the metal develops a strong bond with oxygen linked to sulfur atom (M-O-S) to form a condensed structure.

\section{3. Magnetic Properties}

Generally, the mineral part of the lamellar structure of hybrid compounds is the origin of magnetic properties. Some organic hydroxysulfate, such as, $\mathrm{Co}_{4}\left(\mathrm{SO}_{4}\right)(\mathrm{OH})_{6}\left(\mathrm{C}_{6} \mathrm{~N}_{2} \mathrm{H}_{12}\right)_{0.5} \cdot \mathrm{H}_{2} \mathrm{O}$ that contain a stack of inorganic layers between which the organic molecules are located, can display an interesting magnetic feature thanks to the strong interaction between the metallic centers due to the MO-M bond [50]. The magnetic measurements of the hybrid sulfate salts templated by 2methylpiperazine $\left(\mathrm{C}_{5} \mathrm{H}_{14} \mathrm{~N}_{2}\right)\left[\mathrm{M}^{\mathrm{II}}\left(\mathrm{H}_{2} \mathrm{O}\right)_{6}\right]\left(\mathrm{SO}_{4}\right)_{2}(\mathrm{M}=\mathrm{Mn}, \mathrm{Fe}, \mathrm{Co}$ and $\mathrm{Ni})$, belonging to the tutton's salt family with their zero-dimensional structures, revealed a typical paramagnetic behavior with negligible interactions [46]. The peculiarity of the lamellar atomic arrangement found in our materials, while still supramolecular, motivated us to test their magnetic response. 
The magnetic susceptibility was determined for $\left(\mathrm{C}_{4} \mathrm{H}_{7} \mathrm{~N}_{2}\right)_{2}\left[\mathrm{Co}\left(\mathrm{H}_{2} \mathrm{O}\right)_{6}\right]\left(\mathrm{SO}_{4}\right)_{2} \cdot 2 \mathrm{H}_{2} \mathrm{O}$ over the temperature range of $2-300 \mathrm{~K}$ in a 1000 Oe magnetic field. The magnetic susceptibility and its inverse evolutions versus temperature shows that susceptibility values follow a Curie-Weiss law (fig. 5), with a Curie constant $C$ of 2.3 and a Curie-Weiss $\theta=-14$ K, typical of an Co (II) complex with negligible interactions [51]. The $\chi$.T product (fig. 6) decreases at low temperatures, approaching a value of 1.4 as $\mathrm{T}$ approaches zero, again in agreement with single ion anisotropy. The values of the results found indicate that the compound is predominantly paramagnetic with weak antiferromagnetic interactions.

\section{Conclusion}

The use of the aromatic diamine 2-methylimidazole as organic part in the synthesis of hybrid double sulfates salts of transition metals provided a new structural type in the family of sulfates and their derivates, characterized by a lamellar stack with a fully supramolecular network. i.e., a stacking of supramolecular inorganic layers templated with chains of protonated amines formed by $\pi-\pi$ interaction connection between their aromatic moieties. Hence, the interlayer distance in the compounds of the general formula $\left(\mathrm{C}_{4} \mathrm{H}_{7} \mathrm{~N}_{2}\right)_{2}\left[\mathrm{M}^{\mathrm{II}}\left(\mathrm{H}_{2} \mathrm{O}\right)_{6}\right]\left(\mathrm{SO}_{4}\right)_{2} \cdot 2 \mathrm{H}_{2} \mathrm{O}$ with $\left(\mathrm{M}^{\mathrm{II}}=\mathrm{Zn}\right.$, Co and $\left.\mathrm{Mn}\right)$

reached 11.6 $\AA$. The variation of this distance may depends on the nature of the amine incorporated between the mineral layers. Moreover, a thermal study showed that despite the existence of hydrogen bonds and $\pi$ interactions weak builders of supramolecular network, these compounds showed a good thermal stability with appearance of crystalline anhydrous phases in temperature. Besides, magnetic measurements determined for cobalt based compound indicate a paramagnetic behavior supporting the weakness of the exchange interactions.

\section{Supporting Information}

Crystallographic data for CCDC 1048342 (CoMZL) can be obtained free of charge from The Cambridge Crystallographic Data Centre via www.ccdc.cam.ac.uk/data_request/cif. 


\section{Acknowledgments}

The authors gratefully acknowledge the Ministry of Higher Education, Scientific Research and Information and Communication Technologies (Tunisia) and the Doctorate School of Chemistry, Université de Rennes 1, for financial support. We acknowledge the CDIFX (Centre de Diffractometrie X) - Institut des Sciences Chimiques de Rennes for supplying single-crystal data collection. The authors thank I. Marlart for her assistance in DSC-TG measurements and T. Guizouarn for his assistance in SQUID magnetic measurements.

\section{References}

[1] C. Sanchez, B. Julián, P. Belleville, M. Popall, J. Mater. Chem., 2005, 15, 3559.

[2] A. L. Mohana Reddy, S. R. Gowda, M. M. Shaijumon, P. M. Ajayan, Adv. Mater., 2012, 24, 5045.

[3] C. Sanchez, P. Belleville, M. Popall, L. Nicole, Chem. Soc. Rev., 2011, 40, 696.

[4] A. Dolbecq, E. Dumas, C. R. Mayer and P. Mialane, Chem. Rev.,2010, 110, 6009.

[5] C. N. R. Rao, A. K. Cheetham and A. J. Thirumurugan, Phys. Condens. Matter, 2008, 20, 083202.

[6] L. Qian, E. Willneff, H. Zhang, Chem. Commun., 2009, 3946.

[7] M. Higuchi, D. Tanaka, S. Horike, H. Sakamoto, K. Nakamura, Y. Takashima, Y. Hijikata, N. Yanai, J.Kim, K. Kato, Y. Kubota, M. Takata, S. Kitagawa, J. Am. Chem. Soc., 2009, 131, 10336.

[8] J. Lee, O. K. Farha, J. Roberts, K. A. Scheidt, S. T. Nguyen, J. T. Hupp, Chem. Soc. Rev., 2009, 38, 1450.

[9] G. Centi, S. Perathoner, Microporous Mesoporous Mater., 2008, 107, 3.

[10] R. Masse, J. Zyss, Eur. Patent EP0488869B1 , 1996, 06,1996.

[11] N. Leblanc, N. Mercier, L. Zorina, S. Simonov, P. Auban-Senzier, C. Pasquier, JACS, 2011, $133,14924$.

[12] C. N. R. Rao, J. N. Behera, M. Dan, Chem. Soc. Rev., 2006, 35, 375.

[13] T. Bataille, D. Louër, J. Solid State Chem., 2004, 177, 1235. 
[14] A. J. Norquist, M. B. Doran, D. O’Hare, Inorg. Chem., 2005, 44, 3837.

[15] C. Gérardin, T. Loiseau, G. Férey, F. Taulelle and A. Navrotsky, Chem. Mater., 2002, 14, 3181.

[16] H. B. Yao, M. R. Gao and S. H. Yu, Nanoscale, 2010, 2, 323.

[17] C. N. R. Rao, S. Natarajan, A. Choudhury, S. Neeraj and A. A. Ayi, Acc. Chem. Res., 2001, 34, 80.

[18] N. Leblanc, M. Allain, N. Mercier and L. Sanguinet, Cryst. Growth Des., 2011, 11, 2064.

[19] W. Bi, N. Louvain, N. Mercier, J. Luc, I. Rau, F. Kajzar and B. Sahraoui, Adv. Mater., 2008, 20, 1013.

[20] A. P. Wight, M. E. Davis, Chem. Rev., 2002, 102, 3589.

[21] M. Fleck, L. Bohatý and E. Tillmanns, Solid State Sci., 2004, 6, 469.

[22] T. Bataille, Acta Crystallogr., Sect. C: Cryst. Struct. Commun. , 2003, 59, 459

[23] W. Rekik, H. Naïli, T. Mhiri and T. Bataille, Acta Crystallogr., Sect.E: Struct. Rep., 2005, 61, 629.

[24] F. Hajlaoui, S. Yahyaoui, H. Naili, T. Mhiri and T. Bataille, Inorg. Chim. Acta, 2010, 363, 691.

[25] O. Kammoun, T. bataille, A. Luca, V. Dorcet, I. Marlart, W. Rekik, H. Naili, T. Mhiri, Inorg. Chem., 2014, 53, 2619.

[26] O. Kammoun, W. Rekik, H. Naili, and Thierry Bataille, New J. Chem, 2015, 39, 2682.

[27] O. Kammoun, W. Rekik, T. Bataille, K. T. Mahmudov, M. N. Kopylovich and H. Naïli, Journal of Organometallic Chemistry, 2013, 741, 136.

[28] A. Altomare, M. C. Burla, M. Camalli, G. L. Cascarano, C. Giacovazzo, A. Guagliardi, A. G. G. Moliterni, G. Polidori, R. Spagna, J. Appl. Crystallogr., 1999, 32, 115.

[29] Sheldrick, G. M. ACTA Crystallogr. Sect. A, 2008, 64, 112.

[30] C. Janiak, J. Chem. Soc., Dalton Trans., 2000, 21, 3885.

[31] N. J. Singh, S. K. Min, D. Y. Kim and K. S. Kim, J. Chem. Theory Comput., 2009, 5, 515. 
[32] D. Mekhatria, S. Rigolet, C. Janiak, A. Simon-Masseron, M. A. Hasnaoui, § and A. Bengueddach. Cryst. Growth Des. 2011, 11, 396.

[33] B. G. Hernandez, J. K. Maclaren, H. A. Hoppe, J. Pasan, J. Sanchiz and C. Janiak, CrystEngComm 2012, 14, 2635.

[34] Jana K. Maclaren, Christoph Janiak, Inorg. Chim. Acta, 2012, 389, 183.

[35] A. C. Chamayou a, M.A. Neelakantan, S. Thalamuthu, C. Janiak, Inorg. Chim. Acta, 2011, 365, 447.

[36] B. G. Hernandez, H. A. Hoppe, J. K. Vieth, J. Sanchiz and C. Janiak, Chem. Commun., 2010, 46, 8270

[37] B. M. Draskovi, G. A. Bogdanovic, M. A. Neelakantan, A. C. Chamayou, S. Thalamuthu, Y. S. Avadhut, J. S. Gunne, S. Banerjee and C. Janiak, Cryst. Growth Des., 2010, 10, 1665.

[38] B. Wu, X. Huang, Y. Xia, X. J. Yang and C. Janiak, CrystEngComm, 2007, 9, 676.

[39] T. Dorn, C. Janiak and K. A. Shandi, CrystEngComm 2005, 7, 633.

[40] T. Bataille, D. Louer, J. Mater. Chem., 2002, 12, 3487.

[41] F. Leroux, C. Taviot-Gueho, J. Mater. Chem., 2005, 15, 3628.

[42] T. Nakamura, M. Ogawa, Langmuir, 2012, 28, 7505.

[43] T. Dorn, A. C. Chamayou and C. Janiak, New J. Chem., 2006, 30, 156.

[44] J. K. Maclaren, J. Sanchiz, P. Gili and C. Janiak, New J. Chem. 2012, 36, 1596.

[45] M. Enamullah, V. Vasylyeva, C. Janiak, Inorg. Chim. Acta, 2013, 408, 109-119.

[46] F. Hajlaoui, H. Naili, S. Yahyaoui, M. M. Turnbull, T. Mhiri and T. Bataille, Dalton Trans., 2011, 40, 11613.

[47] Y. Zidane, A. Ourari, T. Bataille, P. Hapiot, D. Hauchard, J. Electroanal. Chem., 2010, $641,64$. [48] G. Alberti, M. Casciola, U. Costantino, R. Vivani, Adv. Mater., 1996, 8, 291. 
[49] K. D. Demadis, N. Famelis, A. Cabeza, M.A.G. Aranda, R.M.P. Colodredo, A. Infantes-Molina, Inorg. Chem., 2012, 51, 7889.

[50] A. Rujiwatra, C. J. Kepert, J. Am. Chem. Soc., 2001, 123, 10584.

[51] O. Kahn, Molecular Magnetism VCH, New York, 1993.

\section{Figure captions}

Fig. 1: X-ray powder diffraction patterns of $\left(\mathrm{C}_{4} \mathrm{H}_{7} \mathrm{~N}_{2}\right)_{2}\left[\mathrm{M}^{\mathrm{II}}\left(\mathrm{H}_{2} \mathrm{O}\right)_{6}\right]\left(\mathrm{SO}_{4}\right)_{2} \cdot 2 \mathrm{H}_{2} \mathrm{O}$ with $\left(\mathrm{M}^{\mathrm{II}}=\mathrm{Zn}\right.$, Co and $\mathrm{Mn}$ ): ZnMZL and CoMZL : simulated from the single crystal structure; MnMZL: experimental pattern.

Fig. 2: a. Projection of the structure along the crystallographic $a$ axis, showing the lamellar character and the stacking along the $b$ axis.

b. The weak hydrogen bonding between the inorganic entities within the mineral layer, showing its supramolecular aspect.

c. Projection of the structure showing the arrangement of 2-methylimidazolium molecules between mineral layers in [001] direction.

d. Asymmetric unit representation of the structure (metal octahedron is completed by symmetry, symmetry code: $1-x, 1-y, 1-z)$.

Fig. 3: DSC-TG curves for the decomposition of $\left(\mathrm{C}_{4} \mathrm{H}_{7} \mathrm{~N}_{2}\right)_{2}\left[\mathrm{Co}\left(\mathrm{H}_{2} \mathrm{O}\right)_{6}\right]\left(\mathrm{SO}_{4}\right)_{2} \cdot 2 \mathrm{H}_{2} \mathrm{O}$ in air.

Fig. 4: TDXD plot for the decomposition of $\left(\mathrm{C}_{4} \mathrm{H}_{7} \mathrm{~N}_{2}\right)_{2}\left[\mathrm{Co}\left(\mathrm{H}_{2} \mathrm{O}\right)_{6}\right]\left(\mathrm{SO}_{4}\right)_{2} \cdot 2 \mathrm{H}_{2} \mathrm{O}$ in air, showing the successive crystalline phases up to the amorphous phase.

Fig. 5: Temperature dependencies of the magnetic susceptibility and its inverse for $\left(\mathrm{C}_{4} \mathrm{H}_{7} \mathrm{~N}_{2}\right)_{2}\left[\mathrm{Co}\left(\mathrm{H}_{2} \mathrm{O}\right)_{6}\right]\left(\mathrm{SO}_{4}\right)_{2} \cdot 2 \mathrm{H}_{2} \mathrm{O}$.

Fig. 6: $\chi$.T evolution versus temperature for $\left(\mathrm{C}_{4} \mathrm{H}_{7} \mathrm{~N}_{2}\right)_{2}\left[\mathrm{Co}\left(\mathrm{H}_{2} \mathrm{O}\right)_{6}\right]\left(\mathrm{SO}_{4}\right)_{2} \cdot 2 \mathrm{H}_{2} \mathrm{O}$. 


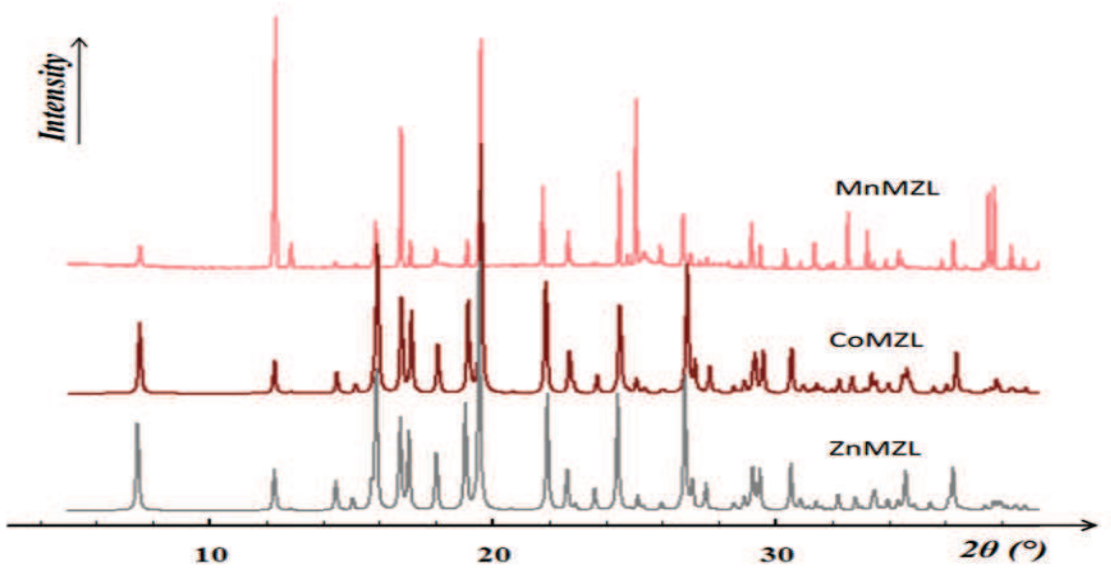

Figure 1 
(a)

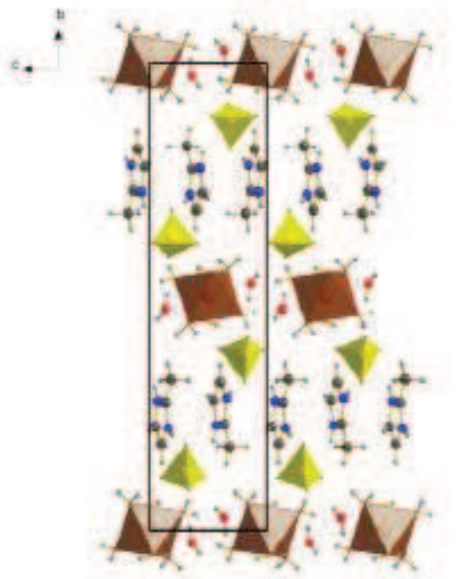

(b)

(c)

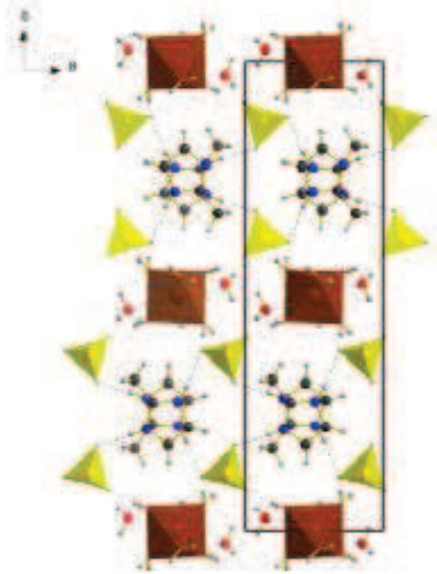

(d)

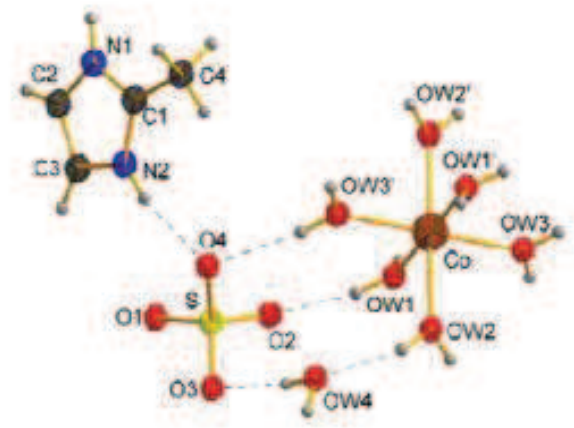

Figure 2 


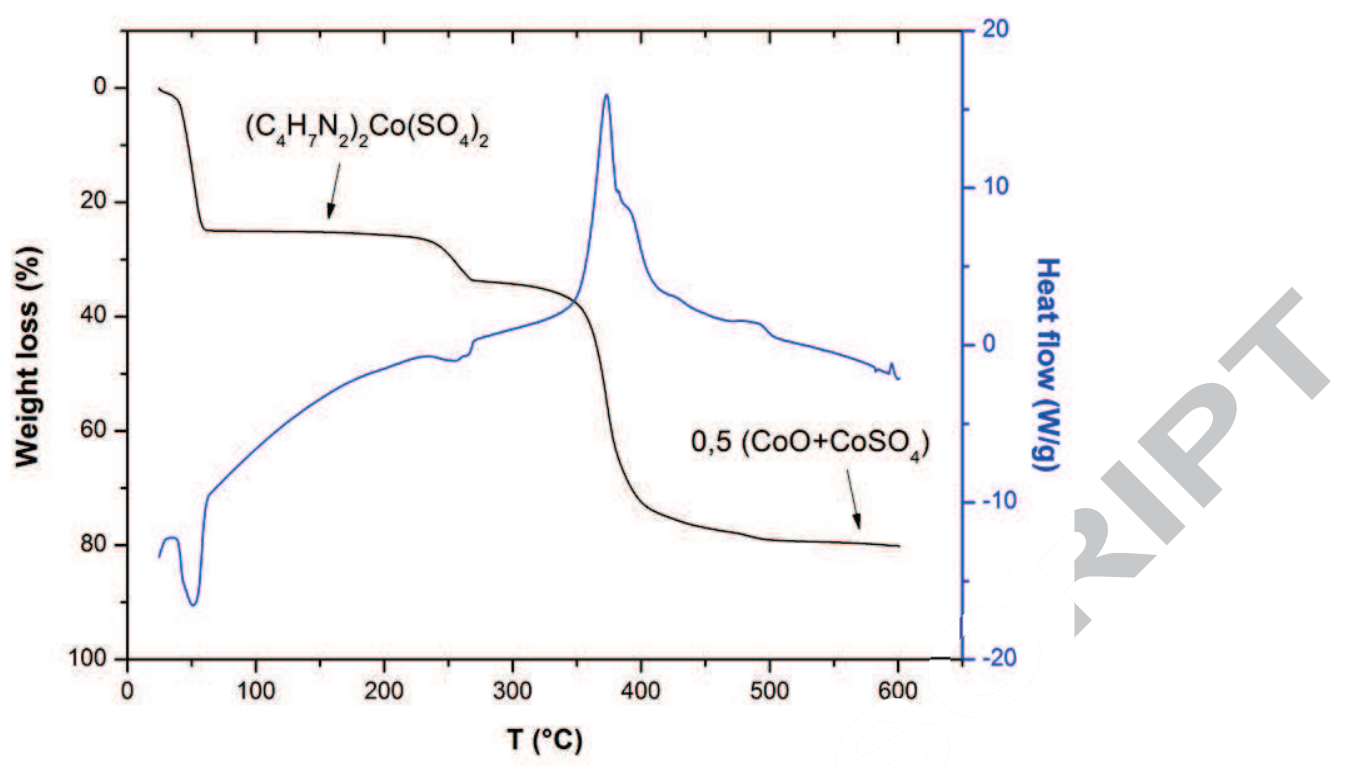

Figure 3 


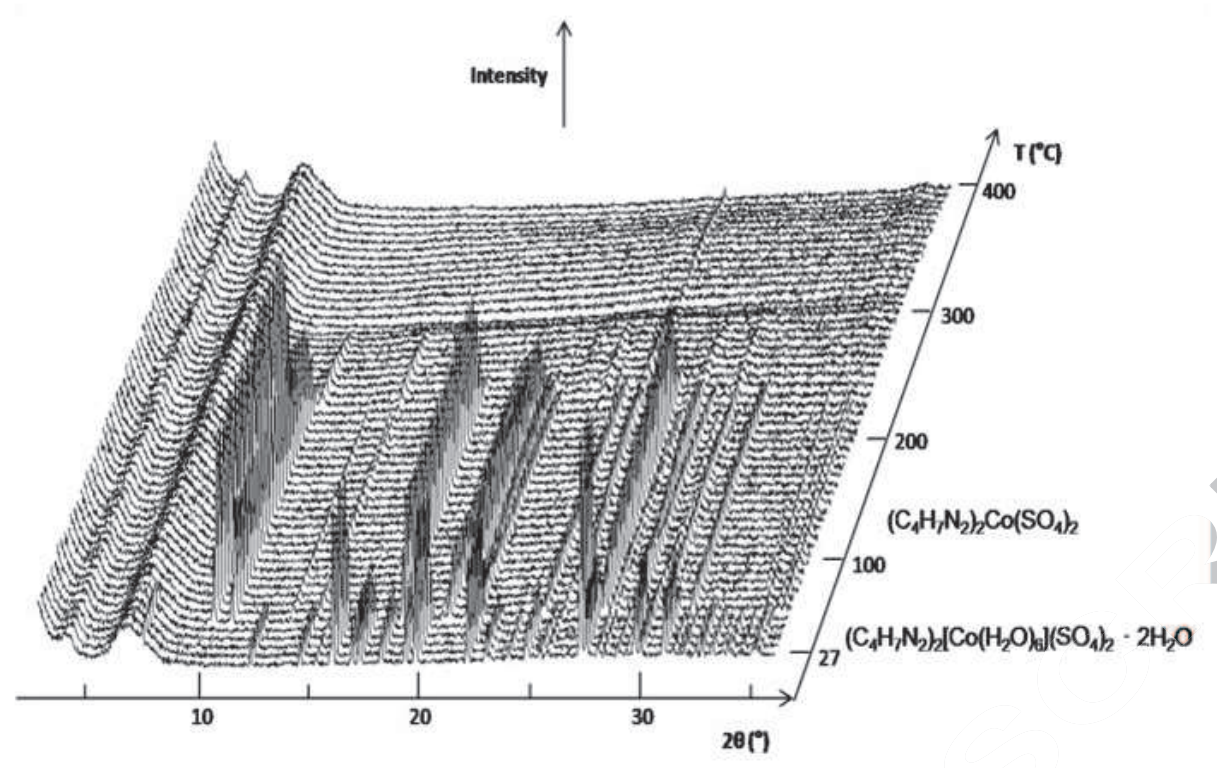

Figure 4 


\section{ACCEPTED MANUSCRIPT}

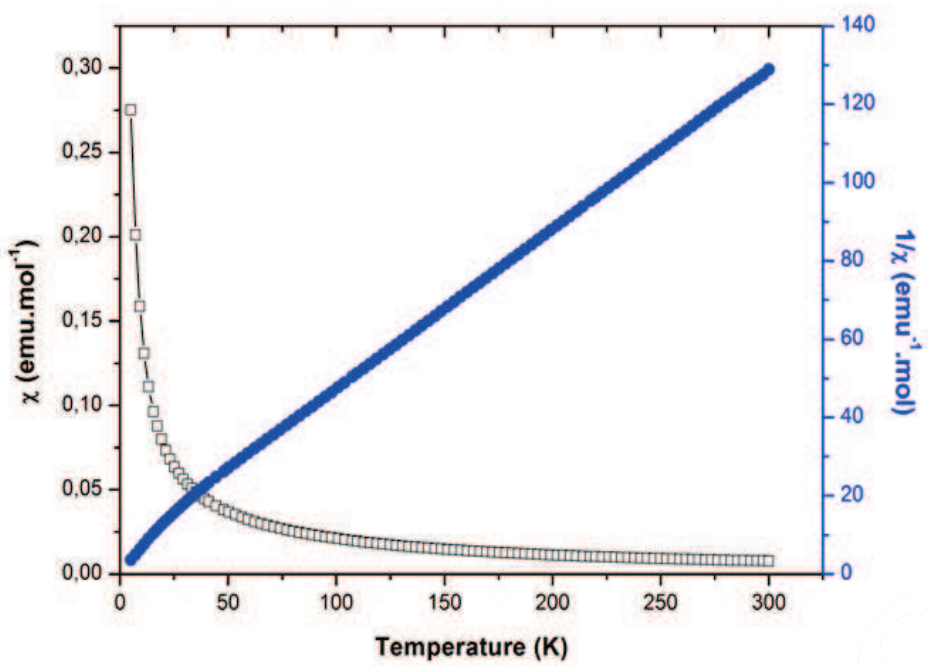

Figure 5 


\section{ACCEPTED MANUSCRIPT}

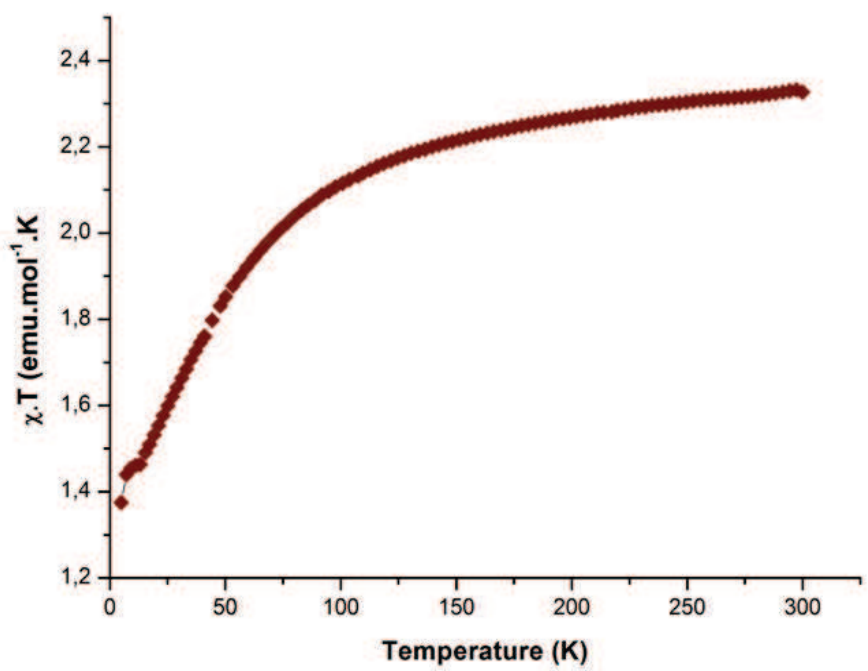

Figure 6 
Table 1: Crystallographic data and structure refinement parameters for $\left(\mathrm{C}_{4} \mathrm{H}_{7} \mathrm{~N}_{2}\right)_{2}\left[\mathrm{Co}\left(\mathrm{H}_{2} \mathrm{O}\right)_{6}\right]\left(\mathrm{SO}_{4}\right)_{2} \cdot 2 \mathrm{H}_{2} \mathrm{O}$.

\begin{tabular}{|c|c|}
\hline Empirical formula & $\mathrm{C}_{8} \mathrm{H}_{30} \mathrm{CoN}_{4} \mathrm{O}_{16} \mathrm{~S}_{2}$ \\
\hline Molecular weight/g mol ${ }^{-1}$ & 561.41 \\
\hline Crystal system & Monoclinic \\
\hline Space group & $P 2_{1} / c$ \\
\hline$Z$ & 2 \\
\hline$a / \AA ̊$ & $7.5783(2)$ \\
\hline$b / \AA$ & $23.2653(7)$ \\
\hline$c / \AA ̊$ & $6.66530(10)$ \\
\hline$V / \AA^{3}$ & $1110.75(5)$ \\
\hline$\beta /^{\circ}$ & $109.059(2)$ \\
\hline Calculated density $/ \mathrm{g} \mathrm{cm}^{-3}$ & 1.679 \\
\hline Crystal size $/ \mathrm{mm}^{3}$ & $0.474 \times 0.041 \times 0.014$ \\
\hline$T / \mathrm{K}$ & 293 \\
\hline$\lambda / \AA$ & 0.71073 \\
\hline$\theta$ range $/^{\circ}$ & $2.91-27.485$ \\
\hline Index ranges & $-9 \leq \mathrm{h} \leq 9,-30 \leq \mathrm{k} \leq 30,-8 \leq 1 \leq 8$ \\
\hline Unique data & 2537 \\
\hline Observed data $[I>2 \sigma(I)]$ & 1978 \\
\hline$F(000)$ & 586 \\
\hline Refinement method & Full-matrix least-squares on $\left|\mathrm{F}^{2}\right|$ \\
\hline$R_{1}[I>2 \sigma(I)]$ & 0.0651 \\
\hline$R_{1}(\mathrm{All})$ & 0.0819 \\
\hline $\mathrm{w} R_{2}[I>2 \sigma(I)]$ & 0.1667 \\
\hline $\mathrm{w} R_{2}(\mathrm{All})$ & 0.1851 \\
\hline Goodness of fit & 1.072 \\
\hline No. of parameters & 174 \\
\hline Largest difference map peak and hole/e $\AA^{-3}$ & 2.145 and -0.853 \\
\hline
\end{tabular}


Table 2: Temperatures of the dehydration and decomposition stages for $\left(\mathrm{C}_{4} \mathrm{H}_{7} \mathrm{~N}_{2}\right)_{2}\left[\mathrm{M}^{\mathrm{II}}\left(\mathrm{H}_{2} \mathrm{O}\right)_{6}\right]\left(\mathrm{SO}_{4}\right)_{2} \cdot 2 \mathrm{H}_{2} \mathrm{O}\left(\mathrm{M}^{\mathrm{II}}=\mathrm{Zn}, \mathrm{Mn}\right)$ given from TDXD analyses.

\begin{tabular}{|l|c|c|}
\hline $\begin{array}{l}\text { Thermal } \\
\text { evolution }\end{array}$ & ZnMZL & MnMZL \\
\hline $\begin{array}{l}\text { Full } \\
\text { dehydration }\end{array}$ & $41^{\circ} \mathrm{C}$ & $50^{\circ} \mathrm{C}$ \\
\hline Phase change & $113^{\circ} \mathrm{C}$ & $93^{\circ} \mathrm{C}$ \\
\hline $\begin{array}{l}\text { Anhydrous } \\
\text { decomposition }\end{array}$ & $242^{\circ} \mathrm{C}$ & $193^{\circ} \mathrm{C}$ \\
\hline
\end{tabular}


Graphical abstract - pictogram

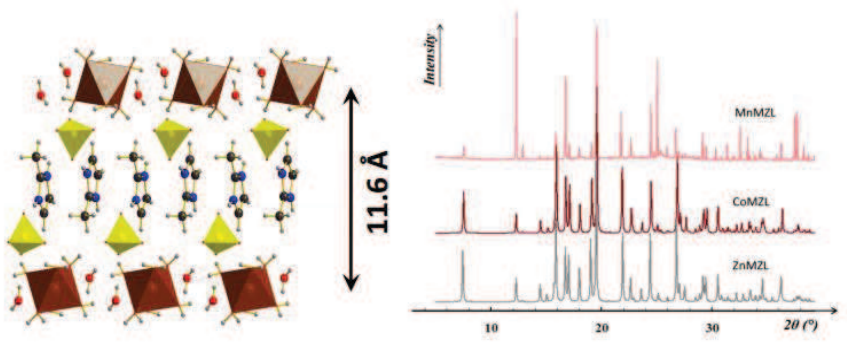




\section{Graphical abstract - synopsis}

The templating effect of 2-methylimidazolium amine in hybrid sulfate salts of transition metal known as supramolecular materials provided a layered structure type with an interlayer distance of $11.6 \AA$. 
Highlights:

- A supramolecular hybrid sulfate salts templated by 2-methylimidazolium amine.

- The crystal structure show a lamellar stack with an interlayer distance of $11.6 \AA$.

- Thermal dehydration showed an important thermal stability.

- The paramagnetic behavior of this class of hybrid materials was highlighted. 